\title{
Evaluation of Physical and Compositional Properties of Horse-chestnut (Aesculus indica) Seed
}

\author{
Syed IR*, Sukhcharn S and Saxena DC
}

Department of Food Engineering and Technology, Sant Longowal Institute of Engineering and Technology, Longowal, Punjab, India

\begin{abstract}
An investigation was carried out on the physical and compositional properties of Horse Chestnut seeds found in Kashmir valley, India. Physical properties such as seed shape and size, geometric and arithmetic mean diameter, sphericity, aspect ratio, bulk and true density, density ratio, porosity, angle of repose and static friction coefficient were determined. The average seed length, width and thickness were 4.7, 4.0 and $3.2 \mathrm{~cm}$, respectively. Geometric and arithmetic mean diameter was 3.92 and $3.97 \mathrm{~cm}$. Average sphericity and aspect ratio was 83.4 and $85.11 \%$, respectively. The average true density, bulk density, density ratio and porosity of the variety was $1072 \mathrm{~g} / \mathrm{cm}^{3}, 518 \mathrm{~g} /$ $\mathrm{cm}^{3}, 48.32 \%$ and $51.68 \%$, respectively. The mechanical property viz., angle of repose values obtained on plywood, mild steel, stainless steel and galvanized sheet were $22.3^{\circ}, 20.3^{\circ}, 18.3^{\circ}$ and $22.79^{\circ}$ for the seed variety. The coefficient of static friction obtained on plywood, mild steel, stainless steel and galvanized sheet were $0.54,0.52$, 0.51 and 0.52 , respectively. The force required to break the seed was $328 \mathrm{~N}$. Color and compositional analysis of the seed powder was conducted. The $L$, $a$ and $b$ value were found to be $92.07,3.47$ and 13.70 with a whiteness value of 83.78 . The powder was having moisture $(12.71 \%)$, protein $(6.78 \%)$, fat $(3.27 \%)$, ash $(3.16 \%)$, fibre $(6.34 \%)$ and carbohydrate $(67.74 \%)$ with energy value of $327.51 \mathrm{cal} / 100 \mathrm{~g}$.
\end{abstract}

Keywords: Horse chestnut; Sphericity; Porosity; Bulk density; Force

\section{Introduction}

Horse Chestnut (Aesculus indica Caleb.) known as handun is a fast growing tree species mainly found in temperate regions of Asia particularly in India, Nepal, Pakistan and Afghanistan. In India, the tree occupies moist and shady ravines of Jammu and Kashmir, Himachal Pradesh and Uttar Pradesh [1,2], with an average height of about $22.5 \mathrm{~m}$, having an upright straight cylindrical bole with spreading crown, and produces huge quantity of seeds every year. There are two varieties of Horse Chestnut viz, budh handun and lakut handun found in Kashmir valley. Seed is covered with a capsule and single seed being present in each capsule [3]. The seeds are about $3.5 \mathrm{~cm}$ in diameter, round in shape, with a hard shiny black rind from outside and lime white cotyledons inside [4].

Flour from the seeds is used for making halwa and also mixed with wheat flour to prepare chapattis [5]. It has also been used as food during the times of famine by various tribes of North and North-Eastern India. Besides playing a significant role in food and non-food applications, it is well known for its medicinal value [6-13]. Seeds are used to extract oil which is among prominent nine oil yielding tree species used to cure Rheumatic pains in Kashmir [14]. Crushed seeds when fed to cattle are reported to improve the quality and quantity of milk. Oils and fats from the seeds are essential and indispensable ingredients of human and animal diet. The physical properties of agricultural produce are important in designing and constructing equipment and structures for handling, transportation, processing and storage and also for assessing the product quality [15-17]. Physical and mechanical properties of fruit, nut, seed and kernel are important to design equipment for dehulling, nut shelling, drying, oil extraction, and other processes like transportation and storage [18]. Physical properties such as size, shape, sphericity, aspect ratio, true density, bulk density and porosity, and mechanical properties such as coefficient of friction, angle of repose as well as fracture resistance are very important in the design of processing machines for major agricultural crops [19]. Many studies have been reported on the chemical and physical-mechanical properties of fruits and kernels, such as apricot kernel, berries, cherry laurel, cornelian cherry, fresh okra fruit, orange, rose fruit, wild plum etc.

Till date no information is available on physical and mechanical properties of Horse Chestnut seed for design and development of equipment needed for processing of Horse Chestnut seeds into desirable products. The objective of this study was to determine the engineering properties like physical and mechanical properties of Horse Chestnut seeds so that knowledge gained will be used in optimizing machine design parameters for handling, transport, processing and storage of the chestnut seeds. Compositional analysis of the seed powder was also conducted.

\section{Materials and Methods}

\section{Material collection}

Fully matured Horse Chestnut seeds were harvested from the trees located in Anantnag area of J \& K, India and any bruised or diseased seeds were discarded. The seeds were then washed under running potable water to remove surface dirt and air dried and used as basic raw material for the study.

*Corresponding author: Syed IR, Research Scholar, Department of Food Engineering and Technology, Sant Longowal Institute of Engineering and Technology, Longowal-148 106, Punjab, India, Tel: +91-95-011-855-63; E-mail: syedinsha12@gmail.com

Received January 13, 2016; Accepted February 04, 2016; Published February 10,2016

Citation: Syed IR, Sukhcharn S, Saxena DC (2016) Evaluation of Physical and Compositional Properties of Horse-chestnut (Aesculus indica) Seed. J Food Process Technol 7: 561. doi:10.4172/2157-7110.1000561

Copyright: $\odot 2016$ Syed IR, et al. This is an open-access article distributed under the terms of the Creative Commons Attribution License, which permits unrestricted use, distribution, and reproduction in any medium, provided the original author and source are credited. 


\section{Determination of physical and mechanical properties}

Weight: Randomly selected ten seeds were taken for weight measurement on digital weighing balance (M/s. Sartorius Mechatronics Pvt Lt., Bangalore, India) to an accuracy of $0.01 \mathrm{~g}$.

Determination of kernel ratio and shell ratio: The same seeds selected above for weight measurement were taken and deshelled and the kernels obtained thereafter were weighed on digital weighing balance (M/s. Sartorius Mechatronics Pvt Lt., Bangalore, India) [20]. The weight of the single kernel was calculated by taking average of the ten kernels. Kernel ratio was determined according to the Turkish Standard Institute [21] by the formula:

Kernel ratio $(\%)=\frac{\text { Kernel wt. }(\mathrm{g})}{\text { Seed wt. }(\mathrm{g})} \times 100$

However, the shell ratio was also calculated as follows:

$$
\text { Shell ratio }(\%)=\frac{\text { Seed wt. }(\mathrm{g})-\text { Kernel wt. }(\mathrm{g})}{\text { Seed wt. }(\mathrm{g})} \times 100
$$

Determination of size: For determining the physical characteristics 10 seeds were selected randomly and for each seed three linear dimensions were measured, that is (a) length, (b) width, and (c) thickness, using a Vernier calliper (Kanon Instrument, Japan) reading to $0.01 \mathrm{~cm}$.

Determination of shape: The shape was expressed in terms of its sphericity index and aspect ratio. The higher the sphericity value the closer is the shape to a sphere. For the sphericity index $(\phi)$, the dimensions obtained for the 10 selected seeds above for size measurement were used to compute the sphericity index based on the equation [22] as:

$$
\begin{aligned}
& \Phi(\%)=\frac{(X . Y . Z)^{\frac{1}{3}}}{X} \\
& \text { Where, } \\
& \mathrm{X}=\text { length }(\mathrm{L}) \text { in } \mathrm{cm} \\
& \mathrm{Y}=\text { width }(\mathrm{cm}) \\
& \mathrm{Z}=\text { thickness }
\end{aligned}
$$

For the aspect ratio same seeds were selected for conducting the experiment. The aspect ratio $\left(R_{a}\right)$ was calculated as recommended by Mohsenin [23]:

$$
\begin{aligned}
& R_{a}(\%)=\frac{\mathrm{Y}}{\mathrm{X}} \times 100 \\
& \text { Where, } \\
& \mathrm{Y}=\text { Width }(\mathrm{cm}) \text { and } \\
& \mathrm{X}=\text { Length }(\mathrm{cm})
\end{aligned}
$$

Determination of bulk and true density: The bulk density is the ratio of the mass of the sample to its container volume occupied. For bulk density measurement, an empty cylindrical container was filled with seeds to a known volume. Tapping during the filling was done to obtain uniform packaging and to minimize the wall effect, if any. The filled sample was weighed and the bulk density was calculated using the below equation [24];

$$
\begin{aligned}
& \text { Bulk density }\left(\frac{\mathrm{g}}{\mathrm{cm}^{3}}\right)=\frac{M}{V} \\
& \text { Where, }
\end{aligned}
$$

Where,

$$
\mathrm{M}=\text { mass of the sample }(\mathrm{g})
$$

\section{$\mathrm{V}=$ Volume of the filled sample $\left(\mathrm{cm}^{3}\right)$}

The true density is defined as the ratio of mass of the sample to its true volume. It was determined by the toluene displacement method in order to avoid absorption of water during experiment [25]. Five randomly selected seeds were weighed and immersed into a $1000 \mathrm{ml}$ measuring cylinder containing $500 \mathrm{ml}$ of toluene [26,27]. It was ensured that the seeds were submerged during immersion. The net volumetric displacement was recorded from the graduated scale of the cylinder. The true density was then calculated using equation below:

$$
\text { True Density }\left(\mathrm{g} / \mathrm{cm}^{3}\right)=\frac{\text { Weight of seed }(\mathrm{g})}{\text { Rise in tolune level }\left(\mathrm{cm}^{3}\right)}
$$

Determination of density ratio and porosity of seed: The density ratio $\left(D_{r}\right)$ is the ratio of true density to bulk density expressed as percentage as follows:

$$
\mathrm{D}_{\mathrm{r}}=\frac{\tilde{\mathrm{n}}_{t}}{\tilde{\mathrm{n}}_{b}} \times 10
$$

Porosity, $\varepsilon$ (\%) indicates the amount of pores in the bulk material and was calculated as per Demir et al. [24]. The porosity of the seed was calculated from the average values of bulk density and true density using the relationship.

$$
\mathrm{a}(\%)=\left[1-\frac{\tilde{\mathrm{n}}_{b}}{\tilde{\mathrm{n}}_{t}}\right] \times 100
$$

Where,

$$
\begin{aligned}
& \rho_{\mathrm{b}}=\text { Bulk density }\left(\mathrm{g} / \mathrm{cm}^{3}\right) \\
& \rho_{\mathrm{t}}=\text { True density }\left(\mathrm{g} / \mathrm{cm}^{3}\right)
\end{aligned}
$$

Arithmetic and geometric mean diameter: The arithmetic mean diameter $\left(\mathrm{D}_{\mathrm{a}}\right)$ and geometric mean diameter $\left(\mathrm{D}_{\mathrm{g}}\right)$ of seeds were calculated from the geometrical dimensions by the formula given by Dutta et al. [28]. Both arithmetic and geometric mean are expressed in $\mathrm{cm}$ and calculated by the following equations:

$$
\begin{aligned}
& D_{a}=\frac{X+Y+Z}{3} \\
& D_{g}=(X . Y . Z)^{\frac{1}{3}}
\end{aligned}
$$

Where,

$$
\begin{aligned}
& \mathrm{X}=\text { Length }(\mathrm{L}) \text { in } \mathrm{cm} \\
& \mathrm{Y}=\text { Width }(\mathrm{W}) \text { in } \mathrm{cm} \\
& \mathrm{Z}=\text { Thickness }(\mathrm{T}) \text { in } \mathrm{cm}
\end{aligned}
$$

Surface area: Surface area (S) was estimated by the formula corresponding to the geometrical shape. The surface area of seed was determined by using the following equation [28]:

$$
S\left(\mathrm{~cm}^{2}\right)=\pi D_{g}^{2}
$$

Where,

$$
\mathrm{D}_{\mathrm{g}}=\text { Geometrical mean diameter }(\mathrm{cm})
$$

Angle of repose: The dynamic angle of repose is the angle with the horizontal at which the material will stand when piled. It was determined on four surfaces viz., plywood, stainless steel, galvanised steel sheet and mild steel sheet. A regular cylindrical container opened at both ends was placed on each flat surface and filled up to the top with seeds. The container was then lifted up gradually from the surface. The gradual lifting continued until a conical heap was formed [20]. The 
angle of repose $(\Phi)$ was calculated from the height and base radius of the heap formed by following relation [23].

$$
\begin{gathered}
\ddot{\mathrm{O}}=\frac{h}{R} \text { Or } \quad \ddot{\mathrm{O}}=\tan ^{-1} \frac{h}{R} \\
\text { Where, } \Phi=\text { angle of repose }\left(^{\circ}\right) ; \\
\mathrm{h}=\text { height of the pile }(\mathrm{cm}) ; \\
\mathrm{D}=\text { diameter of the pile }(\mathrm{cm})
\end{gathered}
$$

Coefficient of static friction: The coefficient of static friction $(\mu)$ was determined against surfaces of plywood, stainless steel, galvanised steel sheet and mild steel sheet using the inclined plane apparatus [29]. The table was gently raised with the seed on the plane and the angle of inclination to the horizontal at which the seed started sliding was read off with the help of protractor attached to the apparatus. The tangent of the angle was reported as the coefficient of friction [29]. The measurement was done 10 times and calculated as:

$$
\mu=\tan \theta
$$

Breakage test: The Breakage test for the seeds was performed to know the magnitude of the force required to break the seed. The force required for breaking individual Horse Chestnut seeds was done by using a Stable Micro System Texture Analyzer (Model TA-XT2i, Texture Technologies Corp., Scarsdale, New York, U.S.A.). The individual seeds were placed centrally beneath the probe ( $\mathrm{p} / 75$ cylinder probe) and breaking force was determined. The compression test was selected in texture analysis using a $50 \mathrm{~kg}$ load cell and sample was compressed to breakage. The strain required for breakage was recorded using the following conditions: pretest speed: $1.0 \mathrm{~mm} / \mathrm{s}$, test speed: $2.0 \mathrm{~mm} / \mathrm{s}$, post-test speed: $10 \mathrm{~mm} / \mathrm{s}$, compression distance: $15 \mathrm{~mm}$. The values reported were the average of ten readings.

Processing of seeds: The seeds were taken and dehulled manually and the kernels obtained were sliced and dried in tray dryer (M/s. Balaji Enterprises, Saharanpur, India) at $50^{\circ} \mathrm{C}$. The dried chips were then grinded into fine powder in Laboratory grinding mill (M/s. Philips India Limited, Kolkata, India). All chemicals were used of analytical grade.

Color characteristics: Color measurement of powder was carried out in triplicates, using Color Flex Spectrocolorimeter (Hunter Lab Colorimeter D-25, Hunter Associates Laboratory, Ruston, USA). The results were expressed in terms of standard $L^{*}, a^{*}$ and $b^{*}$ values. The functions $\Delta \mathrm{E}$ and whiteness index were also calculated.

Compositional properties: Moisture content, crude protein, fat, and ash content of flour was determined according to AOAC methods [29]. Total carbohydrate content was determined according to the difference method by Mathew et al. [30] that is, by subtracting the sum of the percentages of crude protein, lipid, crude fiber and ash content from 100 [31].

\section{Results and Discussion}

\section{Physical properties}

The results of the determined physical parameters of the Horse Chestnut seeds are shown in Table 1 . The weight of the variety was found to be $40.8 \mathrm{~g}$ while kernel and shell ratio was found to be 85.71 and $14.29 \%$, respectively. The mean length, width and thickness were found to be $4.7,4.0$, and $3.2 \mathrm{~cm}$, respectively.

The geometric mean diameter and arithmetic mean diameter were expressed in terms of length, width and height and the values calculated

\begin{tabular}{|c|c|}
\hline Property & Horse Chestnut variety \\
\hline Weight of Seed, $\mathrm{g}$ & $40.80 \pm 1.3$ \\
\hline Kernel ratio (\%) & $85.71 \pm 1.2$ \\
\hline Shell ratio (\%) & $14.29 \pm 1.1$ \\
\hline Length, cm & $4.7 \pm 0.29$ \\
\hline Width, $\mathrm{cm}$ & $4.0 \pm 0.28$ \\
\hline Thickness, $\mathrm{cm}$ & $3.2 \pm 0.10$ \\
\hline Geometrical mean diameter $(\mathrm{cm})$ & $3.92 \pm 0.02$ \\
\hline Arithmetic mean diameter(cm) & $3.97 \pm 0.03$ \\
\hline Sphericity, $\%$ & $83.4 \pm 0.01$ \\
\hline Aspect ratio, $\%$ & $85.11 \pm 0.12$ \\
\hline True density, $\mathrm{g} / \mathrm{cm}^{3}$ & $1072 \pm 2.4$ \\
\hline Bulk density, $\mathrm{g} / \mathrm{cm}^{3}$ & $518 \pm 2.8$ \\
\hline Density ratio, $\%$ & $48.32 \pm 1.2$ \\
\hline Porosity, $\%$ & $51.68 \pm 0.5$ \\
\hline Seed mass, $\mathrm{g}$ & $33.75 \pm 2.10$ \\
\hline Surface area $\left(\mathrm{cm}^{2}\right)$ & $48.25 \pm 0.17$ \\
\hline
\end{tabular}

Results are expressed as Mean \pm Standard deviation of ten observations

Table 1: Physical characteristics of Horse Chestnut seed.

are 3.92 and $3.97 \mathrm{~cm}$, respectively. These parameters depend upon the size of the seed, with bigger size seeds having higher values [20]. The parameters are of great value as the dimensions are important in determining aperture size in material separation [32]. These parameters of Horse Chestnut seed may be useful in determining the size of the components of machine for deshelling.

Sphericity and aspect ratio were found to be 83.4 and $85.11 \%$, respectively. Higher sphericity values indicate that seed shape is closed to a sphere, while high aspect ratio indicates that seeds will roll than slide on flat surfaces. This is very important in design of hoppers for machines [31]. However, if aspect ratio value is being close to the sphericity values the seed will undergo a combination of rolling and sliding action on flat surfaces.

The true density, bulk density, density ratio and porosity were 1072 $\mathrm{g} / \mathrm{cm}^{3}, 518 \mathrm{~g} / \mathrm{cm}^{3}, 48.32 \%$ and $51.68 \%$, respectively. Both the true and bulk density characteristics are useful in the estimation of load and hence in the design of load shafts for processing machine. The porosity in the seed is related to sphericity and aspect ratio, which ensure a more compact arrangement of the seeds. These properties may be useful for the bulk storage and transportation of the seed. The average seed mass of the variety was $33.75 \mathrm{~g}$, depending on the size or dimensions of seed. The surface area was $48.25 \mathrm{~cm}^{2}$, respectively and depends on the size of the seed, with higher value for larger sized seed.

\section{Mechanical properties}

The results for static coefficient of friction and angle of repose of Horse Chestnut seeds obtained on plywood, mild steel, stainless steel and galvanized sheet are presented in Table 2. The coefficient of static friction obtained for the variety was 0.54 on plywood, 0.52 on mild steel, 0.51 on stainless steel and 0.52 on galvanized sheet. The static coefficient of friction was higher on plywood followed by mild steel and galvanized steel and lower on stainless steel for both varieties. There was a small difference in the coefficient of friction obtained on mild steel, stainless steel and galvanized steel. The seeds move easily on surfaces due to higher hardness and slippery surface.

The dynamic angle of repose was higher on galvanized steel followed by plywood and mild steel and lower on stainless steel for both varieties. The angle of repose was $22.3^{\circ}$ on plywood, $20.3^{\circ}$ on mild steel, $18.3^{\circ}$ on stainless steel and $22.79^{\circ}$ on galvanized sheet. The values of angle of 
repose are higher due to the smooth seed surface. The average breaking force required for breaking the seeds are $328 \mathrm{~N}$ as shown in Table 2. The average breakage force required to break the seeds are higher due to the thick seed shell.

\section{Color characteristics}

Color is an important quality factor that typically relates to the acceptability, marketability and wholesomeness of foods. Color characteristics of seed powder are shown in Table 3 . The $\mathrm{L}, \mathrm{a}, \mathrm{b}$ values of HCN seed powder were found to be $91.23,3.10$ and 15.07 with a whiteness value of 82.28 .

\section{Compositional analysis}

The data for compositional analysis of seed powder is presented in Table 3. Chemical composition is an important criterion to have an idea about the overall composition and nutritional status of any ingredient. Moisture content of flour is an important quality parameter which determines its shelf life. The results showed that HCN seed powder contain $12.71 \%$ moisture content (Table 3). Usually, low moisture content helps in enhancing the storage stability at ambient temperature as moisture is an important parameter in the storage of flour/powders, very high levels greater than $12 \%$ allow for microbial growth and thus low levels are favourable and give relatively longer shelf life. The seed powder was found to contain about $3.16 \%$ ash. Ash content reflects the quantity of mineral matter present in a substance and higher values of ash content indicates that higher amount of minerals are present. Fat content was found to be $3.27 \%$. Fibre is an important component

\begin{tabular}{|c|c|}
\hline \multicolumn{1}{|c|}{ Property } & Horse Chestnut variety \\
\hline Coefficient of static friction & \\
\hline Plywood & $0.54 \pm 0.04$ \\
\hline Mild steel & $0.52 \pm 0.07$ \\
\hline Stainless steel & $0.51 \pm 0.05$ \\
\hline Galvanised steel & $0.52 \pm 0.06$ \\
\hline Dynamic angle of repose (degrees) & $22.3 \pm 1.4$ \\
\hline Plywood & $20.3 \pm 1.6$ \\
\hline Mild steel & $18.3 \pm 2.5$ \\
\hline Stainless steel & $22.79 \pm 1.2$ \\
\hline Galvanised steel & $328 \pm 5.12$ \\
\hline Breaking force (N) & \\
\hline
\end{tabular}

Results are expressed as Mean \pm Standard deviation of ten observations

Table 2: Mechanical characteristics of Horse Chestnut seed.

\begin{tabular}{|c|c|}
\hline Parameters & Seed powder \\
\hline Color characteristics & \\
\hline $\mathbf{L}^{*}$ & $92.07 \pm 0.49$ \\
\hline $\mathbf{a}^{*}$ & $-3.47 \pm 0.21$ \\
\hline $\mathbf{b}^{*}$ & $13.70 \pm 0.26$ \\
\hline$\Delta \mathbf{E}$ & $\mathrm{NA}$ \\
\hline Whiteness index & $83.78 \pm 0.06$ \\
\hline Compositional properties & $12.71 \pm 1.23$ \\
\hline Moisture (\%) & $6.78 \pm 1.19$ \\
\hline Protein (\%) & $3.27 \pm 0.39$ \\
\hline Crude Fat (\%) & $3.16 \pm 0.05$ \\
\hline Ash (\%) & $6.34 \pm 0.22$ \\
\hline Crude fiber (\%) & 67.74 \\
\hline Carbohydrate (\%) & 327.51 \\
\hline Energy value (Cal/100 g) & \\
\hline
\end{tabular}

Results are expressed as Mean \pm Standard deviation of triplicate observations Table 3: Color and compositional characteristics of Horse Chestnut seed powder. of many complex carbohydrates. It is always found only in plants particularly vegetables, fruits, nuts and legumes. As shown in Table 3, crude fibre content of the seed was found to be $6.34 \%$. Total protein of HCN seed was quantified to be $6.78 \%$. Carbohydrate content was found to be $67.74 \%$ highest from other components.

\section{Conclusion}

The physical properties including seed shape, size, geometric mean diameter, sphericity, bulk density, porosity, surface area, static coefficient of friction and angle of repose were investigated. The study reveals that physical properties of Horse Chestnut seed may be useful in designing equipment for postharvest handling and processing operations like deshelling of seed, pulverisation of seed kernel into flour etc. These properties are necessary for the design of equipments for harvesting, separating, processing, packing and transportation. Compositional analysis of the seed powder conducted revealed the seeds are rich in carbohydrates $67.74 \%$, protein $6.78 \%$ and fibre $6.34 \%$. Therefore, it may be used as potentially attractive source of carbohydrates, protein and crude fibre.

\section{Acknowledgments}

The first author is grateful to university grants commission, New Delhi, India for providing financial assistance in the form of Maulana Azad National Fellowship (MANF).

\section{References}

1. Singh B (2006) Simple process for obtaining beta Aescin from Indian horse chestnut. United States patent application pub. no. US 2006/0030697.

2. Zhang Z, Li S, Lian XY (2010) An overview of genus Aesculus L.: ethnobotany, phytochemistry, and pharmacological activities. Pharmaceutical Crops 1: 24-51.

3. Rafiq SI, Jan K, Singh S, Saxena DC (2015) Physicochemical, pasting rheological, thermal and morphological properties of horse chestnut starch. J Food Sci Technol 52: 5651-5660.

4. Parmar C, Kaushal MK (1982) Aesculus indica. Wild fruits, Kalyani Publishers New Delhi, India.

5. Rajasekaran A, Singh J (2009) Ethnobotany of Indian horse chestnut (Aesculus indica) in Mandi district, Himachal Pradesh. Indian Journal of Traditional Knowledge 8: 285-286

6. Kaul MK (1997) Medicinal plants of Kashmir and Ladhak. Indus Publishing Company, New Delhi.

7. Kaur L, Joseph L, George M (2011) Phytochemical analysis of leaf extract of Aesculus indica. International Journal of Pharmacy and Pharmaceutical Sciences 3: 232-234

8. Chakraborthy GS (2009) Evaluation of Immuno modulatory action/activity of Aesculus indica. International Journal of Pharma Technological Research 1: 132-134.

9. Chakraborthy GS (2009) Free radical scavenging activity of Aesculus Indica leaves. International Journal of Pharma Technological Research 1: 524-526.

10. Singh B, Katoch M, Raja R, Zaidi A (2007) Inst of Himalayan Bioresource Tech A, Palampur. A new original agent from Indian Horse Chestnut Aesculus Indica European Patant EP1489910.

11. Ikram M, Gilani SN (1986) Anti-inflammatory activity of Aesculus indica fruit oil. Fitoterapia 57: 455-456.

12. Qayum A, Ahmed N, Ahmad KD, Gilani NU (1988) Pharmacological screening of indigenous medicinal plants. Pak J Pharm Sci 1: 37-39.

13. Bhatt JP (1992) Neurodepressive action of a piscicidal glycoside of plant Aesculus indica (Colebr.) in fish. Indian J Exp Biol 30: 437-439.

14. Sharma PK (1991) Herbal remedies for treating rheumatic pains in Jammu and Kashmir. Indian Journal of Forestry 14: 206-210.

15. Sirisomboon P, Pornchaloeampong P, Romphophak T (2007) Physical properties of green soybean: Criteria for sorting. Journal of Food Engineering 79: 18-22. 
Citation: Syed IR, Sukhcharn S, Saxena DC (2016) Evaluation of Physical and Compositional Properties of Horse-chestnut (Aesculus indica) Seed. J Food Process Technol 7: 561. doi:10.4172/2157-7110.1000561

Page 5 of 5

16. Kashaninejad M, Mortazavi A, Safekordi A, Tabil LG (2006) Some physical properties of Pistachio (Pistacia vera $L$ ). nut and its kernel. Journal of Food Engineering 72: 30-38.

17. Plange BA, Baryeh EA (2003) The physical properties of Category B cocoa beans. Journal of Food Engineering 60: 219-227.

18. Sirisomboon P, Kitchaiyab P, Pholphoa T, Mahuttanyavanitcha W (2007) Physical and mechanical properties of Jatropha curcas $L$. fruits, nuts and kernels. Biosystems Engineering 97: 201 - 207.

19. Owolarafe OK, Olabige MT, Faborode MO (2007) Physical and mechanical properties of two varieties of fresh oil palm fruit. Journal of Food Engineering 78: $1228-1232$.

20. Calisir S, Aydin C (2004) Some physical-mechanical properties of cherry laurel (Prunus lauracerasus L.) fruits. Journal of Food Engineering 65: 145-150.

21. TSI (1990) Methods TS 1275 and TS 1276. Ankara, Turkey.

22. Karababa $E$ (2006) Physical properties of popcorn kernels. Journal of Food Engineering, 72: 100-107.

23. Mohsenin NN (1980) Physical Properties of Plant and Animal Materials. Gordon and Breach Science Publishers, New York.

24. Demir F, Dogan H, Ozcan M, Haciseferogullari H (2002) Nutritional and physical properties of hackberry (Celtis australis L.). Journal of Food Engineering 54: 241-247.
25. Mwithiga G, Sifuna MM (2006) Effect of moisture content on the physical properties of three varieties of sorghum seeds. Journal of Food Engineering 75: 480-486.

26. Ovelade OJ, Odugbenro PO, Abiove AO, Raji NL (2005) Some physical properties of African star apple (Chrysophyllum alibidum) seeds. Journal of Food Engineering 67: 435-440.

27. Goyal RK, Kingsly ARP, Kumar P, Walia H (2007) Physical and mechanical properties of aonla fruits. Journal of Food Engineering 82: 595-599.

28. Dutta SK, Nema VK, Bhardwaj RK (1988) Physical properties of gram. Journal of Agricultural Engineering Research 39: 259-268.

29. AOAC (2006) Official Methods of Analysis. Association of Official Analytical Chemists, AOAC Press, Gaithersburg.

30. Mathew T, Al-Bader M, Bou-Resli MN, Dashti HM, Al-Zaid NS, et al. (2006) Alteration of brain zinc level in rat pups of zinc supplemented mothers. Trace Elementary Electrolytes 23: 231-236.

31. Moshsenin NN (1978) Physical Properties of animal and plant material. Gordon and Breach Science Publishers, USA.

32. Omobuwajo TO, Sanni LA, Balami YA (2000) Physical properties of Sorrel Seed. Journal of Food Engineering 45: 37-41. 